\title{
TAXATION OF COMPENSATORY STOCK OPTIONS: CAPITAL GAIN OR ORDINARY INCOME*
}

FoR tax purposes ${ }^{1}$ courts divide stock options given to corporation executives $^{2}$ into two categories: proprietary options designed to develop long-term loyalty to stockholders, ${ }^{3}$ and compensatory options, ${ }^{4}$ which, like cash, are

* Commissioner v. Stone's Estate, 210 F.2d 33 (3d Cir. 1954); ArcNamara v. Commissioner, 210 F.2d 505 (7th Cir. 1954).

1. The question of whether or not an option is compensation may arise in a number of ways: (a) the Commissioner may seek to tax the employee on the exercise spread, claiming it is compensation; Commissioner v. Smith, 324 U.S. 177 (1945); Van Dusen v. Commissioner, 166 F.2d 647 (9th Cir. 1948); (b) the Commissioner may attempt to deny the employer a deduction for compensation; Gardner-Denver v. Commissioner, 75 F.2d $3 \mathrm{~S}$ (7th Cir. 1935); Alger-Sullivan v. Commissioner, 57 F.2d 3 (5th Cir. 1932); (c) the statute of limitations having barred a claim of compensation at exercise, the Commissioner may try to reduce the basis of the employee's stock; Merhengeod Corp. v. Helvering, 89 F.2d 972 (D.C. Cir. 1937); Bothwell v. Commissioner, 77 F.2d 35 (10th Cir. 1935).

2. Executive stock options have been popular since the $1920^{\circ} \mathrm{s}$. They thrive in inflationary periods when large corporate profits are expceted. For a general discussion of their use, terms and profitableness see Baker, Stock Options for Erccutices, 19 HAns. Bus. REv. 106 (1940).

The Treasury first moved to tax stock options in 1923. T.D. 3435, II-1 Cuss. BuLL 50 (1923). Since then they have provoked a great deal of litigation and comment. In general see Alexander, Employee Stock Options and the 1950 Recenue Act, o Tax L. RE. 165 (1951) ; Atlas, Tousard a Conccpt of Compensations, 2 TAx L. REv. 85 (1946); Boland, Employee Options Under the Federal Incone Tax, 28 TAxes 415 (1950); Dean, Employee Stock Options, 66 Harv. L. Kev. 1403 (1953); Ferrall, Employee Stocl: Oplions and the Smith Case, 1 TAX L. REv. 225 (1946); Friedman \& Silbert, Stodt Oglions and Stock Purchase Plans, N.Y.U. 8tr Inst. ox Fen. TAx. 433 (1950); Lyon, Employec Stock Purchase Arrangements, 31 TAXes 1021 (1953); Lyon, Employec Slock Options Under the Revenue Act of 1950, 51 CoL L. Rev. 1 (1951); Tyler, Stoch Options, 24 TAXES 611 (1946); Comment, 56 YALE L.J. 706 (1947).

Stock options have been issued to investment bankers in return for underwriting services since 1692. Haven, Investarent Bankma Under tBe Securities aidd EXCHANGe Cominission 110 (1940). For a discussion of such options see id. at 110 ef seq. Options have also been granted by corporations to their customers. 2 Dewric, Frsis:ant. Policy of Corporations 1216 (4th ed. 1941). See Fozrster \& Dieteh, Eurployes Stcect OWNERSHIP IN THE UNITED STATES (1927) for a survey of options held by non-exccutive employees. Gramans \& Dodd, Security ANarysis c. 46 (1st ed. 1934) is a study of stock options from a securities viewpoint.

3. Philip J. LoBue, 22 T.C. No. 58 (1954); Abraham Rosenberg, 20 T.C. 5 (1953); Delbert B. Geeseman, 38 B.T.A. 258 (1938) ; cf. Edward Egan, P-H 1953 TC MIEs. DEC II 53,266 (1953) (independent contractor). Proprietary options are designed to narrovi the separation of ownership and management begun in post Civil War years. Their function is to make it possible for managers to become owners. Lyon, Employec Stocl: Purchase Arrangements, 31 TAXES 1021 (1953). The corporation seels to have the exceutive devote himself to the permanent interest of the stockholders rather than to his own shorter affiliation as employee.

By a 1950 amendment to the Code Congress permitted corporations to issue to their employees restricted options which receive favorable tax treatment. INT. Rev. Cone of 
payments for services. ${ }^{5}$ Though the distinction has been questioned, ${ }^{0}$ courts continue to hold that if an option is proprietary, neither the value of the option nor the stock yielded by its exercise is taxable income to the employee.

$1939, \S 130 \mathrm{~A}$. To qualify an option must: (a) be granted in connection with cmployment; (b) have a maximum issue spread of $15 \%$; (c) be transferrable only by death, and during the employee's life be exercisable only by him; and (d) not be issued to employees holding more than $10 \%$ of the employer's stock. The benefits are lost if the stock is sold within two years of the grant of the option or within six months of exercise. See Lyon, Employec Stock Options Under the Revenue Act of 1950, 51 CoL. L. Rev. 1 (1951). Section 130A was liberalized by the 1954 Code. INT. REv. CODE $\$ 421$. Many corporations have been induced to change their proprietary options to qualify under the Act. Proposed Accounting Rule, SEC Press Release No. 4803-X, Feb. 25, 1953. However, an option which docs not qualify under $\$ 130 \mathrm{~A}$ may still be proprietary if T.D. 5507, 1946-1 CvN. BuLL. 18, is not upheld. See authorities cited in note 26 infra; cf. James C. Hazelton, P.H 1953 TC Mra. DEC. If 53,123 (1953).

4. Compensatory options are designed to enable employees to make bargain purchases of their employers' stock. Connolly's Estate v. Commissioner, 135 F.2d 64 (6th Cir. 1943); Albert Russel Erskine, 26 B.T.A. 147 (1932); Charles E. Sorenson, 22 T.C. No. 44 (1954). For a discussion of the criteria used to distinguish compensatory and proprietary options, see note 8 infra.

Compensatory options may be issued in return for an agreement not to compete; Salvage v. Commissioner, 76 F.2d 112 (2d Cir. 1935), aff'd, 297 U.S. 106 (1936); and they may be issued by a stockholder rather than by the corporation; Van Dusen v. Commissioner, 160 F.2d 647 (9th Cir. 1948).

5. Many types of benefits have been used to compensate employees. Old Colony Trust Co. v. Commissioner, 279 U.S. 716 (1929) (income taxes) ; Allen v. Commissioner, 107 F.2d 151 (4th Cir. 1939) (stock); J. H. McEwen, 6 T.C. 1018 (1946) (trust fund); George Matthew Adams, 18 B.T.A. 381 (1929) (insurance premiums) ; Ralph Kitchen, 11 B.T.A. 855 (1928) (hotel accomodations). But of. Arthur Benaglia, 36 B.T.A. 838 (1937) (not compensation if for convenience of employer).

6 . "[T] he old regulation, which made the test turn on the existence of compensation, was a little like repealing the law of gravity. I really do not see how it is possible to give a stock option to an executive which is not available to anyone else, without its being compensation." Letter from Erwin N. Griswold, Dean, Harvard Law School, rcprinted in Surrey \& WarRen, Federal Income Taxation 603 (2d ed. 1953); Atlas, supra note 2, at 91-2; Comment, 56 YALE L.J. 706, 712 (1947); Wentz, Remedying the Effoct of Taxation on Management Ozenership of Corporate Stock, 48 N.U.L. REv. 442, 458 (1953). The Supreme Court has not ruled on the question but has indicated in a dictum that the concept of compensation is very broad. See Commissioner v. Smith, 324 U.S. 177, 181 (1945).

In 1923 the Commissioner took the position that all options were compensatory. T.D. 3435, II-1 Cum. Buru. 50 (1923). But the courts disagreed with him, see cases cited note 7 infra, and in 1939 the Commissioner recognized non-compensatory options. T.D. 4879, 1939-1 Cum. Bull. 159. Following the Snith decision, supra, the Commissioner returned to his 1923 ruling. T.D. 5507, 1946-1 Cum. Bull. 18. However, it does not seem that T.D. 5507 will be upheld. Cf. Commissioner v. Stone's Estate, 210 F.2d 33 (3d Cir. 1954); and see note 26 infra.

7. Despite T.D. 3435, II-1 CuM. BuLL. 50 (1923), non-compensatory options were recognized in Rossheim v. Commissioner, 92 F.2d 247 (3d Cir. 1937); Merhangood Corp. v. Commissioner, 89 F.2d 972 (D.C. Cir. 1937); and Delbert B. Geeseman, 38 B.T.A. 258 (1938). Cases decided after Smith have also applied the distinction. Philip J. LoBuc, 22 T.C. No. 58 (1954); Abraham Rosenberg, 20 T.C. 5 (1953); Norman G. Nicolson, 13 
On the other hand, if an option is regarded as compensatory, ${ }^{8}$ the tax consequences differ. In this situation courts have held that the amount of compensation is the difference between the market value of the stock at exercise and the price called for by the option. ${ }^{9}$ This "exercise spread" has been taxed at ordinary income rates at the time of exercise. ${ }^{10}$

Two recent cases, however, allow the employee to pay tax on part of the exercise spread at capital gain rates. 11 They do so by regarding the option itself as compensation rather than as a contract right to acquire compensation." Only the option's value at receipt is considered income $;^{13}$ a subsequent increase in value realized by sale is viewed as a capital gain. ${ }^{14}$

T.C. 690 (1949) ; cf. Ray A. Noland, P-H 1953 TC MEsr. DEC. $\{$ 53,28S (1953). But see Wanda V. Van Dusen, 8 T.C. 388, 391-3, aff'd, 166 F.2d 647 (9th Cir. 1948).

8. Courts say that the intent of the employer and the executive determines whether an option is compensatory. Philip J. LoBue, 22 T.C. No. 58 (1954); Abraham Rosenberg, 20 T.C. 5 (1953). But see Wanda V. Van Dusen, S T.C. $38 S, 391-3$ (1947), aff'd, 166 F.2d 647 (9th Cir. 1948). However, testimony as to intent carries little weight. See Albert Russel Erskine, 26 B.T.A. 147 (1932). Nor do recitals govern. Abraham Rosenberg, 20 T.C. 5 (1953). A deduction by the employer may show his intent, Willkie v. Commissioner, 127 F.2d 953 (6th Cir. 1942), but it is not binding on the employee. Estate of Lauson Stone, 19 T.C. 872, 878 (1953).

It is extremely diffcult for courts to ascertain the intent of parties in this area. Blodgett, Deferred Compensation of Executizes, N.Y.U. GTH Ixst. Ox FED. T.S. 764, 812 (1948). Sax, Stock Options, 23 Taxes 505 (1954), advises optionees of fifty characteristics which should be associated with their options in order to establish a proprietary intent; he warns of thirty-eight to be avoided as indicating a compensatory plan. But the factor on which the courts place most weight is the issue spread. Lyon, Employee Stock: Options Under the Revenue Act of 1950, 51 CoL L. Rev. 1, S (1951).

Whether the intent of the parties is relevant has been questioned. Atlas, supra note 2 at 91-2; Comment, 56 Y ALE L.J. 706, 707 (1947). It may be argued that Commissioner v. Smith, 324 U.S. 177 (1945), where the court found a compensatory intent despite the absence of an issue spread, in effect removed the intent question. T.D. 5507, 1946-1 Cuss. Burl. 18, adopted this interpretation. But see cases cited note 7 sipra. And ef. Bugardus v. Commissioner, 302 U.S. 34 (1937).

9. E.g., Connolly's Estate, 45 B.T.A. 374 (1941), aff'd, 135 F.2d 64 (Cth Cir. 1943); Edward J. Epsen, 44 B.T.A. 322 (1941) ; Albert Russel Erskine, 26 B.T.A. 147 (1932).

10. See cases cited note 9 supra. Prior to Commissioner v. Stone's Estate, 210 F.2d 33 (3d Cir. 1954), there were no decisions on whether the sale price of the option would be income to the executive if it were sold instead of exercised. But sec Commissioner v. Smith, 324 U.S. 177, 181 (1945). I.T. 3795, 1946-1 Cus. Buzl. 15, considers the sale price compensation if the taxpayer disposes of the option in an arms length transfer.

11. Commissioner v. Stone's Estate, 210 F.2d 33 (3d Cir. 1954); MfeNamara v. Commissioner, 210 F.2d 505 (7th Cir. 1954).

12. Commissioner v. Stone's Estate, 210 F.2d 33, 35 (3d Cir. 1954); MreNamara v. Commissioner, 210 F.2d 505, 508-10 (7th Cir. 1954). Both cases relied on a dictum by Chief Justice Stone in the Smith case: "It of course does not follow that in other circumstances not here present the option itself, rather than the proceeds of its excrcise, could not be found to be the only intended compensation." Commissioner v. Snith, 324 U.S. 177,182 (1945).

13. Commissioner v. Stone's Estate, 210 F.2d 33, 35 (3d Cir. 1954); McNamara v. Commissioner, 210 F.2d 505, 50S-10 (7th Cir. 1954).

14. Commissioner v. Stone's Estate, 210 F.2d 33, 34 (3d Cir. 1954) ; cf. Ben F. Read, 
In McNamara $v$. Commissioner ${ }^{15}$ the employee was given a two-year option which he exercised the following year. In Commissioner v. Stonc's Estate ${ }^{10}$ the executive made a bargain purchase of a five-year option which he sold after more than six months had elapsed. In both cases the taxpayers reported the receipt of their options as compensation, estimating their values. ${ }^{17}$ Both courts held that the option was property with a market value and was the intended compensation. ${ }^{18}$ The two decisions skirted I.T. $3795^{10}$ in which the Treasury had adopted the exercise spread formula. In Stone it was distinguished by both the Tax Court ${ }^{20}$ and the Third Circuit ; ${ }^{21}$ they held that it applies solely to outright grants of options and not to bargain purchases. ${ }^{22}$ In McNamara the Tax Court found no need to determine the applicability of the I.T. because the court thought the evidence showed the exercise spread was the intended compensation. ${ }^{23}$ The Seventh Circuit reversed the finding of

P-H 1954 TC MEN. DEC. I 54,044 (1954). In Store the court relied on a Treasury regulation, T.D. 5507, 1946-1 Cuns. BuLc. 18, to reach this conclusion, but it rejected the Treasury's contrary interpretation of the regulation in I.T. 3795, id. at 15. Commissioner v. Stone's Estate, 210 F.2d 33, 34-5 (3d Cir. 1954).

An increase confirmed by exercise is not taxed immediately since exercise is not a taxable event. Cf. Helvering v. San Joaquin Co., 297 U.S. 496, 500 (1936) ; MAGiLL, TAXABLE Incone 119 (1936). However, the increase is taxed as a capital gain when the employee sells his stock. INT. REv. CoDE $\$ \S 1012,1222$. But if the option remains unsold at the employee's death, its basis is revalued, and no capital gain is realized by the employee or his estate. INT. Rev. CODE $\S 1014$. If the optionee is a stockholder, exercise may be a taxable event. See note 30 infra. For a discussion of the tax consequences when an option expires, see note 66 infra.

15. 210 F.2d 505 (7th Cir. 1954). McNamara's option had an issue spread of $\$ 3.00$. It was assignable, but exercise, which was not conditioned on M[cNamara's continued employment, had to be in installments. McNamara v. Commissioner, 210 F.2d 505, 506, 507 (7th Cir. 1954).

16. 210 F.2d 33 (3d Cir. 1954). The option issued to Stone had a minus issue spread of $\$ 1.25$. After six months it was exercisable by bearer, but at all times the optionee was protected against dilution of his option. Estate of Lauson Stone, 19 T.C. 872, 874 (1953).

17. Commissioner v. Stone's Estate, 210 F.2d 33, 34 (3d Cir. 1954); McNamara v. Commissioner, 210 F.2d 505, 507 (7th Cir. 1954).

Stone's estimate was later used as a basis for figuring his capital gain. Commissioner v. Stone's Estate, 210 F.2d 33, 34 (3d Cir. 1954). MeNamara's estimate will become part of the basis of his stock. T.D. 5507, 1946-1 Cun. BuLL. 18.

18. See note 12 supra. Cf. John C. Wahl, 19 T.C. 651 (1953).

19. 1946-1 Cuar. Bull. 15. The I.T. was announced simultancously with T.D. 5507, 1946-1 Cuar. Buil 18, which ruled that all employee options issued after February 26, 1945 , were compensatory.

20. Estate of Lauson Stone, 19 T.C. 872,878 (1953).

21. Commissioner v. Stone's Estate, 210 F.2d 33, 34 (3d Cir. 1954).

22. Commissioner v. Stone's Estate, 210 F.2d 33, 34-5 (3d Cir. 1954). The advice in I.T. 3795, 1946-1 Cum. Bull. 15, was directed to the taxing of an option granted to an employee. However, the I.T. also provides for the lapse of an option paid for by an employec. Id. at 16; cf. T.D. 5507, id. at 18; and see Commissioner v. Smith, 324 U.S. 177, 181 (1945). The distinction of the Third Circuit appears to be based on the idca that, in calling the exercise spread compensation in every case, the Treasury is creating income by regulation. See discussion in note 26 infra.

23. Harley v. McNamara, 19 T.C. 1001 (1953). 
intent ${ }^{24}$ but failed to discuss the I.T. ${ }^{25}$ Both decisions are in accord with the trend of hostility towards the Treasury formula. ${ }^{20}$ They indicate that it will not be upheld, but if it is, Stone points the way to avoidance by use of the bargain purchase device.

Stone and McNamara attempt to remove a distinction between employees and investors created by earlier cases. ${ }^{27}$ Formerly most employees holding

In the Smith case the Supreme Court ruled that the measure of compensation was based on the intent of the corporation and the employee. Commissioner v. Smith, 324 U.S. 177 (1945). Following this approach the Tax Court rached the same result it would have had it applied the I.T. The court thought that the sale price of the option was unknown and that the parties did not contemplate a sale. Also, since the option was exercisable in stages, the taxpayer might have to malie a sacrifice if he disposed of it immediately. Furthermore, he expected its value to increase as a result of his services, an increase a present purchaser might not be willing to recognize. Therufore, the Tax Court concluded that the exercise spread was the intended compensation. Id. at 1010-1.

24. The court agreed that the option was intended to be compensatory, MreNamara v. Commissioner, 210 F.2d 505, 507-8 (7th Cir. 1954), but three factors persuaded the court that the contemplated compensation was the option itself: (a) the refercnees in the option and the employment contract to compensation for the year of issue; (b) reporting the issue of the option by the employer and the employee in their tax returns, and (c) the fact that the issue spread was kept constant during several months of negotiations. $I d$. at 508-9.

In previous cases the words used by the parties were of little or no effect. Clarence L. Landen, 1. T.C.M. 411, 415 (1943) ("legalistic verbiage"); Albert Russel Ersline, 26 B.T.A. 147, 157 (1932) (look to the thing, not the language) ; $x$. Herbert H. Springford, 41 B.T.A. 1001, 1002 (1940) (proprietary option despite compensatory language); Gordon M. Evans, 38 B.T.A. 1406, 1407 (1938) (same). Nor has the tax action tatien by the parties been determinative. Abraham Rosenberg, 20 T.C. 5 (1953); Estate of Lauson Stone, 19 T.C. 872 (1953) ; $c f$. Charles E. Sorensen, 22 T.C. No. 44 (1954). While MICNamara's employer kept the issue spread approximately constant, his withloolding McNamara's right to immediate exercise was inconsistent wtih a desire to grant nrecisely the issue spread. 1ICNamara v. Commissioner, 210 F2d 505, 507 (7th Cir. 1954).

25. The taxpayer argued that the I.T. was inapplicable because it was retroactive and was not justified by the case law. Brief for Petitioner, pp. 25-30, McNamara v. Commissioner, 210 F.2d 505 (7th Cir. 1954). But seo Commissiuner v. Smith, 324 U.S. 177, 181 (1954); Wanda V. Van Dusen, \& T.C. 3SS, 391-3 (1947), afi d, 166 F.2d 647 (9th Cir. 1948). For a discussion of the Treasury's authority to make regulations sce Eisenstein, Some Iconoclastic Refiections on Tax Administratiun, 58 Hars. L. Rav. 477 (1945). See also Comment, 56 YaLE L.J. 705, 715 (1947).

26. The first case decided after Smith did not think the intent question was cliniriated, James M. Lamond, P-H 1946 TC Mear. DEC. 【46,023 (1946). And later cases have followed suit. See, e.g., Norman G. Nicolson, 13 T.C. 690 (1949); MIalcolm C. Clark, P-H 1950 TC Mear. DeC. I 50,210 (1950) ; James C. Hazelton, P-H 1953 TC Mes. Des: If 53,123 (1953); Philip J. LoBue, 22 T.C. No. 58 (1954). See also Lyon, Employac Stúct: Options Under the Reventue Act of 1950, 51 CoL. L. Rev. 1, 12-17 (1951). But sce Wanda V. Van Dusen, 8 T.C. 388, 391-3 (1947), aff'd, 166 F.2d 647 (9th Cir. 194S). A Cungressional committee has suggested the Commissioner's rulings were invalid: "[Y]uur committee believes these regulations go beyond the decision of the Supreme Court in Commissioner v. Smith. . . The resulting uncertainty as to whether these regulations are in accordance with the law is an additional reason for legislative actiun. . ." SE: REP. No. 2375, 81st Cong., 2d Sess. 59 (1950).

27. See cases cited note 9 supra and note 29 infra. Compare Commissioner v. Smith, 
compensatory stock options were taxed at ordinary income rates when their options increased in value, ${ }^{28}$ while non-employee investors possessing similar options received capital gain treatment. ${ }^{20}$ The Stonc-McNamara position is that where an employee relinquishes part of his salary in return for a stock option, the employee has made an investment and should be taxed accordingly. ${ }^{30}$

In removing this disparity Stone and McNamara introduce several others. The first is a distinction between employees holding options and those with profit-sharing employment contracts not qualified under Section 401 of the Code. ${ }^{31}$ The profit-sharer is not taxed on the value of the sharing clatuse at the time he enters into his contract, ${ }^{32}$ and when his profits are realized they are taxed at ordinary rates. ${ }^{33}$ Yet the two devices are functionally similar. Both are designed to make executive compensation vary with business pros-

324 U.S. 177 (1945), with Ben F. Read, P-H 1954 TC MeM. Dec. ๆ 54,044 (1954). Sce Comment, 56 Yale L.J. 706, 710 (1947). In no case was an employee issucd an option identical to those being traded on securities markets. In such a situation the taxpayer might possibly have prevailed with the argument that proved successful in Stonc and McNamara. But cf. Connolly's Estate v. Commissioner, 135 F.2d 64 (6th Cir. 1913) (option with large issue spread which could have been sold); Albert Russel Erskine, 26 B.T.A. 147 (1932) (option with assignable value).

28. See authorities cited notes 9 and 27 supra.

29. E.g., Mack v. Commissioner, 148 F.2d 62 (3d Cir. 1945); Merhengood Corp. v. Helvering, 89 F.2d 972 (D.C. Cir. 1937); Harold B. Franklin, 34 B.T.A. 927 (1936); cf. Helvering v. San Joaquin Co., 297 U.S. 496 (1936). See also G.C.M. 23677, 1943 CuM. Bull. 370 .

The cost of the option plus the price called for at its exercise comprise the stock's basis. When the stock is sold, the bargain purchase yielded by the option is taxed as a capital gain. INT. REv. CODE $\$ \S 1012,1222$. For the treatment of the lapse of an option, see note 66 infra.

30. "Authorities aside there would seem to be little trouble about this problem since the law does make a distinction between capital gain and ordinary income. . . . It would seem, then, as a matter of principle that when the taxpayer received this thing of value ... and turned it into cash ... that, it being a 'capital transaction;' he should be treated as in any other capital transaction. ... ." Goodrich, J., Commissioner v. Stone's Estate, 210 F.2d 33, 34 (3d Cir. 1954). See Lyon, Employee Stock Purchasc Arrangements, 31 TAXES 1021, 1027 (1953).

Note that an option (stock right) issued by a corporation to its stockholders may be a concealed dividend. Choate v. Commissioner, 129 F.2d 684 (2d Cir. 1942); cf. Charles M. Cooke, Ltd., 2 T.C. 147 (1943). If so, it is taxable at the time of exercise or sale. There is a conflict of authority as to the amount of dividend income. Compare G.C.M. 25063, 1947-1 Cum. Bull. 45 (exercise spread), with Choate v. Commissioner, 129 17.2d 684, 687 (2d Cir. 1942) (lesser of the exercise or issue spreads).

31. INr. Rev. Cone $\S 401$. This section was formerly part of $\S 165$ of the 1939 Code.

32. Cf. Block \& Kohner Co. v. United States, 37 F.2d 877 (8th Cir. 1930); George K. Gann, 41 B.T.A. 388 (1940); Thurlow E. McFall, 34 B.T.A. 108 (1936). See also cases cited note 33 infra.

33. Sloane v. Commissioner, 188 F.2d 254 (6th Cir. 1951). This is true even though they come from the sale of the contract rights. E.g., A. L. Parker, 5 T.C. 1355 (19.45); Estate of Thomas F. Remington, 9 T.C. 99 (1947). 
perity. ${ }^{34} \mathrm{~A}$ contract right to share in corporate profits is the more direct technique, but an option's value comes from the same source: corporate income which maintains or advances stock prices. ${ }^{35}$ If the percent of profits were to be paid with stock, the two devices would be almost indistinguishable. ${ }^{30}$ Nor should it be significant that an option may be a separate writing ${ }^{37}$ and contain words of assignability, ${ }^{38}$ for a sharer-employee may also transfer his rights. ${ }^{39}$

34. An empirical study of the use of employee stock options by Balker, Stocl Options for Executives, 19 HARv. Bus. Rev. 106, 109 (1940), shows that options are generally employed when a business needs exceptional performance by its executives to malse it profitable. At the time of founding or reorganizing the prospect of unusually large rewards is used to attract men likely to assure corporate success. See MicNamara v. Commissioner, 210 F.2d 505 (7th Cir. 1954); Garner \& Forsythe, Stock II'arrants and Rights, 4 So. CaLIF. L. Rev. 269, 375, 379 (1931). Deferred compensation is not the heart of stock options because they are not normally used to carry static spreads tax-free to post-retirement years. Rather, it is expected that a large spread will develop in a few years, and the executive will take his profit at that time. Baker, supra at 113-114.

If the position of the taxpayers in Stone and MCNamara were adopted, the issue spread would be taxed immediately, leaving no room for deferred compensation. However, the taxpayer would then have a capital asset giving him the power to determine when to realize capital gain on post-issue appreciation. This might be of great value since the taxpayer could decide to realize gain only in those years in which he had ofisetting capital losses.

35. Grahau \& Dodd, Security Axulysis 543 (1st ed. 1934); Balier, sugro note 34, at 113-114. Speculative stocks may advance without corporate profits, but most issuers of employee options use them at times when profits are expected to cause price rises. See note 34 supra. Options may also have trading values (even in the absence of a spread), and the optionee may take his profit by selling. Garner \& Forsythe, suffro note 34, at 271. But trading prices may not approach the vast gains to be made by exercising (or selling at the peak of the spread), and it is questionable how many employee optionees choose to receive their compensation by this route. For examples of the profitableness of options, see note 54 infra.

36. They would differ only when the optionee failed to exercise; however, Balker, supra note 34, at 113-114, shows that the executive generally will exercise when he thinks his spread is maximum.

37. Many options are incorporated into the employment contract. Balser, stipra note 34 , at 108. To make the tax distinction depend on a second piece of paper is absurd. Cf. Gregory v. Helvering, 293 U.S. 465 (1935). No significance was attached to the fact that MícNamara's option was a separate document. MlcNamara v. Commissioner, 210 F.2d 505 (7th Cir. 1954).

38. The option in the Smith case was assignable, but the Supreme Cuurt did not regard the fact of sufficient importance to require comment. But of. Estate of Lauson Stone, 19 T.C. 872,877 (1953).

A "negotiable" option may not be negotiable within the meaning of the Negotiable Instruments Law since it is not a promise to pay money. See Garner \& Forsythe, supra note 34, at 387-91. Nevertheless an option may be assignable. See Mfanirattan Co. $\vee$ Morgan, 242 N.Y. 38, 50, 150 N.E. 594, 598 (1926). Note that profit made by a corporate executive on the transfer of a stock option within six months of its issue may have to be returned to the employer. 4 STaT. $\$ 81,896$ (1934), 15 U.S.C. $\$ 78(p)$ (1940). Sec, c.g., Gratz v. Claughton, 187 F.2d 46 (2d Cir.), cert. dinied, 341 U.S. 920 (1951). See also Hardee, Stock Options and the "Insider Trading" Procisions of the Secturities Exchange Act, 65 HARv. L. Rev. 997 (1952).

39. State Street Furniture Co. v. Armour \& Co., 345 III. 160, 177 N.E. 702 (1931). The employee's rights need not be earned at the time of assignment. Citizens' Loan 
Moreover, the Stone-McNamara decisions make it possible for corporation executives to reap tax advantages greater than those allowed any other group. ${ }^{40}$ Although in two related areas Congress has made exceptions to the general rule of taxing compensation at ordinary income rates in the year earned, both exceptions carry drawbacks and limitations not present in the rule of Stone and McNamara. Pension and trust plans which qualify under Section 401 of the Code ${ }^{41}$ allow employees to defer the payment of tax and to obtain capital gain advantages ;2 $^{42}$ restricted stock options under Section 421 offer similar features. ${ }^{43}$ But qualified pension and trust plans may not be confined to executives, ${ }^{44}$ and capital gain treatment is severely limited. ${ }^{45}$ Re-

Ass'n v. Boston \& M.R.R., 196 Mass. 528, 82 N.E. 696 (1907). Assignment is possible despite a contractual provision to the contrary. State Street Furniture Co. v. Armour \& Co., 345 Ill. 160, 177 N.E. 702 (1931). Contra: Reef v. Milis Novelty Co., 126 Tex. 380,89 S.W.2d 210 (1936). If assignment is impossible, the employec could contract to take as trustee. See United States v. Drescher, 179 F.2d 863, 866 (2d Cir. 1950). For a general discussion of assignability of profit-sharing rights, see 4 AM. Jur., Assignments, $\$ \S 41-6$ (1936).

40. The tax advantages available to corporation executives through restricted stock options are equalled only by the treatment given to the armed forces in Korca. Lyon, Employee Stock Options Under the Reveme Act of 1950, 51 CoL. L. Rev. 1, 55 n.126 (1951). The Stone-McNamara approach is even more liberal to corporate exccutives since it avoids the limitations imposed by Congress on restricted options. Sec text at notes 46-8 infra.

41. INT. REv. CoDE $\S 401$. This section was formerly part of $\S 165$ of the 1939 Codle.

42. INT. REv. CODE $\$ \$ 401,402,501$ (a). These sections were formerly $\$ 165$ of the 1939 Code. The benefits available under these sections include: (a) emplayers may receive current deductions for compensation expenses, while employces may postpone the reporting of income until payments are received; (b) if all payments are made in a single year after retirement, they qualify for capital gain rates: (c) income carned on employer contributions is not taxed as realized: (d) unrealized valute apprecintion on employer stock may not be taxed at the time of distribution. Furthermore, the risk of employer insolvency is removed. See discussion by Rice, Incentives for Extcculives of Small Corporations, 32 Taxes 222 (1954); Childs, Deferred Compcusation Plans for Executives, 31 TAXES 1007 (1953).

Deferred compensation may also be possible under non-qualified individual contracts. See, e.g., Shuster v. Helvering, 121 F.2d 643 (2d Cir. 1941); James F. Oates, 18 T.C. 570, appealed, P-H Fed. TAX Citator 6154 (7th Cir. 1952) ; Howard Veit, \& T.C. 809 (1947). But under the constructive receipt doctrine there may be immediate taxation. Sec, e.g., Corliss v. Bowers, 281 U.S. 376 (1930); Richard R. Deupree, 1 T.C. 113 (1942). Even if taxation is postponed, there is no opportunity for capital gain treatment.

43. INT. REv. CODE $\S 421$. This section was originally enacted in 1950 as $\S 130 \mathrm{~A}$ of the 1939 Code.

Taxation is postponed until the disposal of stock obtained by exercise. If the issue spread is $5 \%$ or less, all appreciation will be capital gain. An issue spread of $5 \%$ to $15 \%$ will be taxed as ordinary income, with post-issue appreciation treated as capital gain. Sec discussion in Lyon, Employee Stock Options Under the Revemue Act of 1950, 51 CoL. L. Rev. 1 (1951). For the qualifications of restricted options see note 3 supra.

44. Int. Rev. Code $\$ \S 401,501$ (a). See Tavannes Watch Co. v. Commissioner, 176 F.2d 211, 216 (2d Cir. 1949).

45. It is only available if the employee takes all his benefits in the year following separation. INT. Riv. CODE $\S 402$. See discussion in Rice, supra note 42 , at 224 . 
stricted options may not be transferred inter vivos by employees, ${ }^{20}$ and the stock they yield must be held two years after granting of the option. ${ }^{47}$ Furthermore, employers using restricted option plans are denied deductions for compensation. ${ }^{48}$ It is questionable whether courts should strain the concept of investment property ${ }^{49}$ to permit any group benefits greater than those granted by Congress. ${ }^{50}$

Another consequence of Stone and $M C N$ amara is the administrative problem of option evaluation.51 In neither case did the court determine the value of the taxpayer's option since the tax for the year of receipt was not in issue." But it seems likely that value determinations will be the crucial issue in future cases. For if an employee stock option is property, all such assets should be valued and taxed at receipt. ${ }^{53}$ However, an accurate appraisal of every option

46. INT. Rev. Cone $\S 421$ (d) (1).

47. Stock must also be held six months following exercise. Inr. Rev. Cone \$ 421 (3).

48. INr. REv. CoDE $\$ 421$ (a) (2). This might cause minority stockholders to be dissatisfied with a compensatory option scheme. Lyon, Enployee Stock Options Under the Revenue Act of 1950, 51 CoL. L. Rev. 1, 32 (1951).

Note that to qualify for capital gain treatment restricted options must be exercised within three months of the termination of employment. INr. REv. Cove $\$ 421$ (a). Options may not extend for more than ten years or be issued to employees with over 10\% of the voting power of the employer corporation. Id. at $\$ 421(\mathrm{~d})(1)(\mathrm{C}),(\mathrm{D})$.

49. See Mfiller, The "Capital Asset" Concept: A Critique of Capital Gains Taxation, 59 Y ALE L.J. 837, 867-8, 877-8, 1057, 1082 (1950).

50. A restricted stock option pian under INT. Rev. CODE $\S 421$ may appear to offer greater benefits than Stone-1ICNamara. But a different picture is presented when the drawbacks of restricted options are considered. See notes $46-8$ supra, and accompanying text.

The legislative history of $\$ 130 \mathrm{~A}$ of the Code of 1939 , the predecessor of $\$ 421$ of the present Code, should not be interpreted merely as a clarification of existing law. The standards in $\S 130 \mathrm{~A}$ were not adopted to guarantee favorable tax treatment to an indifferent group of optionees, leaving the rest to the possibility of the same treatment under judge-made law. The restrictions of $\S 130 \mathrm{~A}$ show that it was designed to provide proprietary advantages only for those options whose function is to make partners out of employees. Sex. Rep No. 2375, 81st Cong., 2d Sess. 59 (1950). In 1954 the Senate Finance Committee reemphasized that the benefits accorded restricted options were not to be available indiscriminately. SEN. REP. No. 1622, S3d Cong., 2d Sess. 58, 61 (1954). And the Conference Committee agreed. H.R. REP. No. 2543, \$3d Cong., 2d Sess. 44 (1954).

51. Nearly all the commentators recognize this dificulty. Sce Boland, Enployce Options Under the Federal Income Tax, 23 Taxes 415, 420-1 (1950); Wentz, Rennedying the Effect of Taxation on Managenent Oumcrship of Corporate Slocl, 48 N.U.L. Rex. 442, 453 (1953) ; Comment, 56 Y ALE L.J. 706, 713-14 (1947) ; Blodgett, Deferred Conspensation of Executives, N.Y.U. 6TH INST. ON FED. TAX. 764, 816 (1948).

52. The courts merely held that the options had market value. IIcNamara y. Commissioner, 210 F.2d 505, 508 (7th Cir. 1954); Estate of Lauson Stone, 19 T.C. 872, 878 (1953). When the issue to be litigated is the amount of capital gain tas, as in Stonc, or the basis of stock, as in McNamara, it is to the Commissioner's advantage not to dispute the low issue values assigned to their options by taxpayers. In neither of these cases, therefore, did the Commissioner challenge the correctness of the taxpayers" estimates.

53. The fact that an employee accepts an option in lieu of cash salary payments shows it has value Even lack of an issue spread does not eliminate market value. See Gmanss \& Dodd, Security Analysis 550 (1st ed. 1934). 
-including its speculative potential-is impossible. ${ }^{54}$ Thus, if courts are to appraise options whenever their worth is disputed, judges will frequently have to indulge in conjecture. ${ }^{55}$ There may be reluctance to do this. ${ }^{66}$ In earlier

Formal differences between options should not entail different tax results. See text at notes 37-9. Nor should variations on the word "value," such as fair market value, market value or real value, be used to distinguish some options from others. 2 PAUt, Federal Estate and Gift Taxation $\$ 18.02$ (1942).

54. See authorities cited note 51 supra. See also 1 Bonbright, Valdution of PropERTY 348-9 (1st ed. 1937). In addition to valuing the option's speculative potential the court might have to discount the effect of restrictions on the option or the stock. Compare John C. Wahl, 19 T.C. 651 (1953), with Harold H. Kuchman, 18 T.C. 154 (1952), and Robert Lehman, 17 T.C. 652 (1951). See Note, 62 YALE L.J. 832 (1953); Comment, 21 U. of Chi. I. Rev. 464 (1954) ; cf. United States v. Drescher, 179 F.2d 863 (2d Cir. 1950).

The system of valuing puts and calls, an option method of buying and selling stock used by brokers, cannot provide an index to the value of employee options becattse the latter are exercisable for much longer periods of time and may contain restrictions. Garner \& Forsythe, Stock Warrants and Rights, 4 So. CALIF. L. REv. 269, 274 (1931). For the same reasons these options differ from stockholder rights. Gruman \& Dodv, op. cit. supra note 53 , at 542 . The Treasury is vague on the valuation of all stuch rights. I.T. 2509, VIII-2 Cum. ButL. 78, 79 (1929). See Rice, The Valuation of Close Hicld Stocks: A Lottery in Federal Taxation, 98 U. of PA. L. REv. 367 (1950).

To ignore the speculative potential of an option and find market value only in the issue spread as some authorities have suggested, e.g., Revised Acconnting Rescarch Bulletin No. 37, 95 J. Accountancy 310 (1953); Tyler, Stock Options, 24 Taxes 611, 614 (1946), is to ignore a valuable aspect of the option device. The chance to make a future gain is the heart of an option. Bonbright, op. cit. supra at 34S. Options are generally issued to permit employees to make bargain purchases when their employer corporations become more profitable. Baker, Stock Options for Executives, 19 Hukv. Bus. Rev. 106, 109 (1940). Consequently lack of an issue spread does not climinate all value from an option. For examples of the trading prices of options with negative issue spreads see GramaMr \& Dodd, op. cit. supra note 53, at 550. As speculative devices, options may be more profitable than stocks bought on a $50 \%$ margin: during a long upward movement of stock prices options yielded $220 \%$ greater profits; in a downward swing option holders sustained smaller losses. 1 Dewing, Financial. Policy of CokiokaTions 254 (4th ed. 1941). For examples of the profits yielded by some options see Baker, supra at 115 .

An option may be valuable for other reasons. It may enable the optionee to buy stock of a closely-held corporation, Ferrall, supra note 53, at 231, or to hedge against inflation, Dean, Employee Stock Options, 66 Harv. L. Rev. 1403, 1405 (1953). Evcn though an option has an issue spread, it retains these other features, and they should not be ignored in an appraisal.

In Choate v. Commissioner, 129 F.2d 684 (2d Cir. 1942) the speculative value of stock rights was ignored, but the court indicated that a different result might bo reached under section 22(a) of the 1939 Code. Id. at 689. Cf. Commissioner v. Smith, 324 U.S. 177, 181 (1945). In the Smith case, however, the court suggested that value came only from a spread. Ibid. But of. Connolly's Estate v. Commissioner, 135 F.2d 64 (6th Cir. 1943). It was an asserted conflict with Connolly that led the Supreme Court to consider Smith. Commissioner v. Smith, 324 U.S. 177, 178 (1945).

55. See Grant Trust \& Savings Co., 3 B.T.A. 1026, 1029 (1926). See also 2 PauL, Federal Estate and Gift Taxation § 18.04 (1st ed. 1942).

56. In income tax cases courts tend to postpone evaluations of speculative property. E.g., Burnet v. Logan, 283 U.S. 404 (1931); Westover v. Smith, 173 F.2d 90 (9th Cir. 
stock option cases courts declined to evaluate the likelihood of the failure of conditions precedent. ${ }^{\text {th }}$ And elsewhere in tax law they have refused to speculate when appraisals of rights were hazardous because of indefinite yields ${ }^{\mathrm{s}}$ or uncertain conditions of payment. ${ }^{59}$ If the courts choose not to speculate, ${ }^{\text {co }}$ evaluation will be postponed until exercise or sale, ${ }^{01}$ and any appreciation in

1949). In estate tax cases, where later valuation is impossible, courts may value property unwillingly. Sec Burnet v. Logan, supra at 412.

57. Albert Russel Erskine, 26 B.T.A. 147 (1932); John C. Wahl, 19 T.C. 651 (1953); cf. Julian Robertson, 6 T.C. 1060 (1946); John A. MlcPherson, 22 B.T.A. 196 (1931).

58. Burnet v. Logan, 283 U.S. 404 (1931); Westover v. Smith, 173 F.2d 90 (9th Cir. 1949) ; Commissioner v. Carter, 170 F.2d 911 (2d Cir. 1948). Where a reliable index exists, courts may evaluate otherwise speculative property. Boudreau v. Commissioner, 134 F.2d 360 (5th Cir. 1943); Realty Sales Co., 10 B.T.A. 1217 (1923). If postrionement of valuation is impossible, courts may value rights with conditions precedent. Charles T. Kline, 44 B.T.A. 1052 (1941); Belmont Shore Co., 21 B.T.A. 714 (1930).

59. J. Darsie Lloyd, 33 B.T.A. 903 (1936); K. E. Mierren, 18 B.T.A. 156 (1929). However, if payment is merely postponed, the right is valued when granted. J. H. MICEwen, 6 T.C. 1018 (1946); of. Commissioner v. Smith, 324 U.S. 177, on rehcaring, 324 U.S. 695 (1945).

60. A market for the corporation's options would provide certainty for courts. Hazeltine Corp. v. Commissioner, S9 F.2d 513 (3d Cir. 1937); Ramapo, Inc. v. Commissioner, 84 F.2d 986 (2d Cir. 1936). But this would not exist for all ortions. Some corporations, of course, have none of their securities traded. But even corporations whose stock options are sold may issue options to their employees which are different from the options being traded. And though a market exists, peculiar conditions might destroy the reliability of market prices. Heiner v. Crosby, 24 F.2d 191 (3d Cir. 1928). For a discussion of the difficulties in the use of market quotations see 2 PACL, of. cit. supra note 55 , at $\$ \$ 18.23,18.24$.

In other cases evidence that would diminish guesswork might include:

(1) Bona fide offers to purchase the taxpayer's option. Gencrally such ofiers are inadmissible. Sharp v. United States, 191 U.S. 341, 348 (1903); Estate of G. A. E. Kohler, 37 B.T.A. 1019, 1027 (1938). However, under some circumstances offers to buy or sell are admissible. Trustees for Ohio \& Big Sandy Coal Co., 15 B.T.A. 273, 287-8 (1929), rev'd on other grounds, 43 F.2d 782 (4th Cir. 1930) (offer to sell sets maximum value); Manufacturers Paper Co. v. Commissioner, S9 F.2d 6S4 (2d Cir. 1937) (ufier to buy sets minimum value).

(2) Expert opinions. See 2 PaUn, op. cit. supra note 55, at $\$ \S 18.41,18.42$. Expert testimony was introduced in both Stone and MfCNamara. Stone's option, for which he paid $\$ 1,000$, was valued by him and his employer at $\$ 6,000$. Two experts called by Stone valued it at $\$ 25,000$ and $\$ 30,000$ respectively. Brief for Petitioner, p. 23, Commissioner v. Stone's Estate, 210 F.2d 33 (3d Cir. 1954). The Commissioner introduced no experts; however, if value were the issue and the Commissioner called his authorities, the battle of the experts would be on.

(3) A showing that the option's speculative value is so slight that its issue spread is virtually its only worth. Cf. Helvering v. Tex-Penn Co., 300 U.S. 4SI, 499 (1937); United States v. State Street Trust Co., 124 F.2d 9.4 (1st Cir. 1942). While restrictions might reduce value, they may not eliminate it entirely. Cf. United States v. Drescher, 179 F.2d 863 (2d Cir. 1950) ; Heiner v. Gwinner, 114 F.2d 723 (3d Cir.), corl. dinicd, 311 U.S. 714 (1940). Also, the option's value might be due to factors other than its speeulative potential or issue spread. See note 54 supra.

61. Charles E. Sorenson, 22 T.C. No. 4 (1954); John C. Wahl, 19 T.C. 651 (1953); 
value will be taxed at income rates. ${ }^{62}$ Thus, lack of evidence of market value will place some employees in unfavorable tax situations. ${ }^{03}$

Adoption of the Treasury's exercise spread formula appears desirable. This would eliminate the difficulties and inequities inherent in the StoneMcNamara approach; it would also diminish the effectiveness of loading options with restrictions designed to reduce or eliminate their value in the eyes of the court. ${ }^{64}$ Yet employee stock options would retain important tax benefits. ${ }^{65}$ If the corporation's stock declines, the executive will receive no taxable income if he fails to exercise and a reduced amount if he does. ${ }^{\text {ob }}$ If he exercises after retirement or in any other low-income year, his compensation will be re-

Albert Russel Erskine, 26 B.T.A. 147 (1932). Cf. Burnet v. Logan, 283 U.S. 404 (1931) ; Westover v. Smith, 173 F.2d 90 (9th Cir. 1949); Estate of Raymond T. Marshall, 20 T.C. 979 (1953).

62. See cases cited note 9 supra. But cf. Choate v. Commissioner, 129 F.2d 684, 687 (2d Cir. 1942).

63. Taxpayers likely to feel the discrimination will be employees of corporations ton small to have their securities traded in markets. There may be no sales-or infrequent sales-of the stock of such corporations; the probability is greater that there will be no sales of options. In these circumstances valuing an option is highly speculative: after assigning a value to the corporation's stock the court must project the stock's price into the future, estimating the likelihood of the stock price exceeding the exercise price before the option expires; a dollar value must then be assigned to this possibility. If the option or the stock obtainable by exercise contains restrictions, the problem is compounded. Yot the small business employees who would be placed in a disfavored tax position are a group which our national policy seeks to encourage. 67 Stat. 232 (1953), 15 U.S.C.A. $\S 631$ (Supp. 1953).

It has been suggested that the exercise spread formula discriminates against employees who obtain marketable options from employers rather than by purchase on the market. But factually this situation is not likely to arise. For in anticipation of either the Stone-McNamara approach or the exercise spread formula all employees would take their compensation in cash and then buy options on the market.

64. In two recent cases restricted stock given to employees was held to have no taxable value at issue or when the restrictions were removed. Harold H. Kuchman, 18 T.C. 154 (1952) ; Robert Lehman, 17 T.C. 652 (1951). But cf. United States v. Drescher, 179 F.2d 863 (2d Cir. 1950). Even if the restrictions do not remove all value, they may reduce it. For a discussion of the device see Note, 62 Y ALE L.J. 832 (1953) ; Comment, 21 U. of Cerr. L. Rev. 464 (1954); Note, 90 U. of PA. L. Rev. 346 (1941).

65. The employer is benefitted also; the exercise spread is deductible as compensation, not as a capital loss. I.T. 3795, 1946-1 Cum. Butl. 15; Alger-Sullivan v. Commissioner, 57 F.2d 3 (5th Cir. 1932); cf. Gardner-Denver v. Commissioner, 75 F.2d 38 (7th Cir. 1935).

66. I.T. 3795, 1946-1 Cuns. Burl. 15. If the employee were taxed at income rates upon receipt of the option, its expiration would be a short-term capital loss. INT. REv. CODE $\$ 1234$; cf. Nordblom Associates, Inc., 15 T.C. 220 (1950). If the spread declined (and the option presumably decreased in value), but the employee exercised, he would not sustain a capital loss, since exercise is not a taxable occasion. Cf. Helvering v. San Joaquin Co., 297 U.S. 496, 500 (1936) ; Magill, Taxable Incone 119 (1936). Stockholders receiving stock rights as dividends are not taxed until exercise; hence, no income is realized if the optionee fails to exercise. G.C.M. 25063, 1947-1 Cum. BuLL. 45; Eastern Shares Corp., 32 B.T.A. 608 (1935). 
ceived while in a lower bracket. ${ }^{67}$ And if he retains the option until death, neither he nor his estate need report any income. ${ }^{\text {os }}$

An amendment to I.T. 3795 explicitly including bargain purchases would facilitate a judicial return to the exercise spread formula by enabling the bench to distinguish both Stone ${ }^{69}$ and McNamara. ${ }^{70}$ Without Treasury action courts will have to rely on the troublesome question of intent, finding as a fact that the exercise spread is the intended compensation. ${ }^{\pi 1}$

67. Furthermore, the employee may exercise his option over a period of favorable tax years to minimize his gain. Boland, Employee Options Under the Federal Ineone Tax, 28 TAxes 415,420 n.32 (1950). At 1954 rates a married taxpayer with no dependents would save $\$ 27,240$ in income taxes by exercising an option worth $\$ 100,000$ over a five-year period rather than in a single year (assuming other sources of income are exactly offset by available deductions). INT. REv. CODE § 1(a).

It might even be a hardship for the employee to pay the tax at receipt of the option; if he lacked independent cash, he might be forced to sell his option and be unable to capitalize on its speculative feature.

68. INT. Rev. Cone $\$ 1014$, formerly $\S 113$ (a) (5) of the Code of 1939. See, e.g., Hartley v. Commissioner, 295 U.S. 216, modified, 295 U.S. 719 (1935); Commissioner v. Mratheson, 82 F.2d 380 (5th Cir. 1936). The estate will, of course, be taxed on postdeath appreciation. See, for example, Estate of Edgar V. O'Daniel, 10 T.C. 631 (1948); Mack v. Commissioner, 148 F.2d 62 (3d Cir. 1945).

69. Such an amendment would remove the distinction created by Stone which subsequent taxpayers might adopt as an avoidance device. Commissioner v. Stone's Estate, 210 F.2d 33, 34-5 (3d Cir. 1954). See text at notes 20-22.

Stone and McNamara might also be distinguished because both taxpayers disposed of their options prior to the enactment of $\$ 130 \mathrm{~A}$ of the Code of 1939 , the predecessor of $\$-421$ of the present Code. See note 50 supra.

70. McNamara can be distinguished since the Seventh Circuit failed to discuss I.T. 3795. See text at notes 23-5. However, on its face the I.T. was applicable, and the taxpayer was compelled to argue that it was an unjustified statutory interpretation. Erief for Petitioner, pp. 25-30, MicNamara v. Commissioner, 210 F.2d 505 (7th Cir. 1954).

71. See Commissioner v. Smith, 324 U.S. 177 (1945); Charles E. Sorenson, 22 T.C. No. 44 (1954) ; cf. Commissioner v. Stone's Estate, 210 F.2d 33 (3d Cir. 1954); MfeNarmara v. Commissioner, 210 F.2d 505 (7th Cir. 1954). 